\title{
Metabolic Regulation of Leaf Senescence in Sunflower (Helianthus annuus L.) Plants
}

\author{
Eloísa Agüera, Purificación Cabello, \\ Lourdes de la Mata, Estefanía Molina and Purificación de la Haba \\ Department of Botany, Ecology and Plant Physiology, \\ University of Córdoba \\ Spain
}

\section{Introduction}

The leaf is the main photosynthetic organ of plants and its development a complex process governed by a combination of environmental factors and intrinsic and genetically regulated signals (Van Lijsebettens \& Clarke, 1998). Usually, leaf ontogeny includes an early phase of increasing photosynthetic rates while the leaf is actively expanding, a mature phase where such rates peak and a senescence phase where they decline (Gepstein, 1988; Miller et al., 2000). During early development, the leaf is a sink receiving nutrients from the rest of the plant; however, as soon as it reaches full photosynthetic capacity, it becomes the main source organ of the plant. After this productive period, the leaf enters the senescence phase, during which most compounds present in it are removed and reused (Hörtensteiner \& Feller, 2002; Buchanan-Wollaston et al., 2003a). Leaf senescence, which is last stage in leaf development, is a highly regulated and programmed degeneration process governed by a variety of developmental and environmental signals (Lim et al., 2003). This important phase in the leaf lifespan period may last as long as leaf maturation and involves a shift from nutrient assimilation to nutrient remobilization and recycling (Guiboileau et al., 2010). In senescent leaf metabolism, carbon and nitrogen assimilation are replaced by catabolism of chlorophyll and macromolecules such as proteins, RNA and membrane lipids, the degradation of which marks the senescence phase. Unsurprisingly, senescence alters the expression of many genes. These senescence-associated genes include regulatory genes encoding transcription factors; genes involved in degradative processes that code for hydrolytic enzymes such as proteases, lipases and ribonucleases; and genes with secondary functions in senescence that code for proteins involved in nutrient remobilization (e.g. glutamine synthetase, which catalyses the conversion of ammonium into glutamine to enable nitrogen recycling in senescing cells) (Taiz \& Zeiger, 2010). Environmental cues such as day length and temperature, and various biotic and abiotic sources of stress, can also affect the initiation and progress of such a high complex as leaf senescence.

During senescence, some metabolic pathways are triggered and others turned off. These dramatic metabolic changes result in orderly degradation of cellular structures, starting with chloroplasts (Wiedemuth et al., 2005), and also in the subsequent remobilization of the resulting materials. Chloroplasts play a dual role; thus, they are the main source of nitrogen 
and also the regulators of their own degradation during senescence (Zapata et al., 2005). Most of the protein in green cells is located in chloroplasts, which thus constitute their main reserves of organic nitrogen. Efficient recycling of nitrogen from the photosynthetic apparatus during early senescence requires the presence of intact mitochondrial, nuclear and cellular membranes (Gan \& Amasino, 1997; Nam, 1997; Noodén et al., 1997; Hörtensteiner \& Feller, 2002; Cabello et al., 2006). Leaf proteins (particularly photosynthetic proteins) are extensively degraded during senescence (Martínez et al., 2008), which confirms that one of the primary functions of leaf senescence is to recycle nutrients (especially through nitrogen remobilization) (Himelblau \& Amasino, 2001). Protein breakdown starts early in senescence and proteolysis is believed to start within chloroplasts. Some proteins (e.g. chlorophyll-binding light-harvesting proteins LHCII) seem to be entirely degraded within chloroplasts, whereas Rubisco and other chloroplastic proteins may be broken down via a hybrid pathway involving both chloroplasts and extraplastidic compartments such as the central vacuole and small senescence-associated vacuoles (SAVs), which are absent from mature, non-senescing leaves but present in large numbers during senescence (Otegui et al., 2005; Martínez et al., 2008). Degradation of chloroplastic proteins releases potentially phototoxic chlorophylls that necessitate degradation. Therefore, leaf senescence is characterized by a decline in photosynthetic activity and chlorophyll content, and the rapid chlorophyll loss associated with chloroplast degeneration is frequently used as a biomarker for the start of senescence. Although chlorophyll degradation is an early senescence signal, leaf yellowing is not an appropriate marker of early senescence because it is observed when senescence has progressed to a great extent (Diaz et al., 2005). Nitrogen and carbon metabolism plays a crucial role in the senescence process, which is seemingly governed by both external and internal factors. Thus, leaf senescence induction involves the joint action of external (nitrogen availability, light) and internal signals (regulating metabolites, $\mathrm{C} / \mathrm{N}$ ratio) (Wingler et al., 2006; Wingler \& Roitsch, 2008).

Other important signals for induction or progression of senescence include the redox status of leaf cells and the production of reactive oxygen species (ROS) such as hydrogen peroxide and superoxide radical (Kukavica \& Veljovic-Jovanovic, 2004; Zimmermann \& Zentgraf, 2005). There are many sources of reactive oxygen species, which are produced during aerobic metabolism in chloroplasts, mitochondria and peroxisomes in both photosynthetically active and senescent cells. The toxicity of these reactive species is dictated by various enzymatic and non-enzymatic protective antioxidant defences. Superoxide dismutases, catalases, peroxidases and the ascorbate-glutathione cycle enzymes are the primary antioxidant enzymes. Plant ageing increases oxidative stress and the levels of reactive oxygen species, which may additionally diminish antioxidant protection (Buchanan-Wollaston et al., 2003b; Zimmermann \& Zentgraf, 2005). Chloroplasts are probably the main target of age-associated oxidative stress in plants (Munné-Bosch \& Alegre, 2002). Therefore, a plausible model for regulation of leaf senescence is a shifted balance between the production of reactive oxygen species and their removal by antioxidant systems.

In this chapter, we describe various aspects of leaf senescence in sunflower plants, with special emphasis on changes in the contents of some nitrogen and carbon metabolites potentially acting as regulators or markers of senescence during sunflower leaf development, and also on the role of oxidative stress in this process and the influence of external factors such nitrogen supply and irradiance exposition on it. 


\section{Growth-related parameters and photosynthetic activity during sunflower leaf senescence}

We examined various markers widely used to monitor leaf development (viz. photosynthetic pigment level, protein content and $\mathrm{CO}_{2}$ fixation rate) in primary leaves of sunflower plants grown for 42 days. The start of senescence in sunflower plants was associated with a considerable decrease in protein content and specific leaf masses referred as weight (Table 1).

\begin{tabular}{ccc}
\hline $\begin{array}{c}\text { Leaf age } \\
\text { (days) }\end{array}$ & $\begin{array}{c}\text { Soluble protein } \\
\left(\mathrm{mg} \mathrm{g}^{-1} \mathrm{DW}\right)\end{array}$ & $\begin{array}{c}\text { Specific leaf mass } \\
\left(\mathrm{mg} \mathrm{DW} \mathrm{cm}^{-2}\right)\end{array}$ \\
\hline & & \\
16 & $152.3 \pm 9.4$ & $2.2 \pm 0.11$ \\
22 & $178.5 \pm 7.7$ & $3.1 \pm 0.28$ \\
28 & $108.1 \pm 4.6$ & $3.0 \pm 0.27$ \\
36 & $89.6 \pm 1.9$ & $2.5 \pm 0.23$ \\
42 & $62.2 \pm 1.4$ & $2.2 \pm 0.29$ \\
\hline
\end{tabular}

Table 1. Changes in soluble protein and specific leaf mass during sunflower primary leaf ageing. Data are means \pm SD for duplicate determinations in three separated experiments.

These changes may reflect alterations in $\mathrm{N}$ and $\mathrm{C}$ compound distributions as a consequence of $\mathrm{N}$ remobilization, the efficiency of which is related to the ratio between biomass in the sink and source organs (Wiedemuth et al., 2005; Diaz et al., 2008). Since chloroplasts contain the largest amounts of protein in leaves, their breakdown releases most of the nitrogen that is reused by other plant organs. The mechanisms behind chloroplast degradation in senescing leaves are poorly understood (especially those for the degradation of Rubisco and chlorophyll-binding light-harvesting proteins, which are the most abundant chloroplastic proteins) (Martínez et al., 2008). Chloroplasts contain a large number of proteases, some of which are encoded by senescence-associated genes, which are up-regulated during senescence. Degradation of some thylakoid proteins such as LHCII seemingly occurs exclusively within chloroplasts and requires the prior release and breakdown of pigments (Hörtensteiner \& Feller, 2002; Buchanan-Wollaston et al., 2003a). CND41 protease is believed to be involved in Rubisco degradation and in the translocation of nitrogen during senescence in tobacco leaves (Kato et al., 2004, 2005). However, the central vacuole and SAVs also play a role here, as they help complete the degradation of Rubisco and other stromal proteins (Martínez et al., 2008). The relative rates of degradation of some photosynthetic components may be altered by the environmental conditions. Thus, LHCII degradation in rice is delayed by low irradiances (Hidema et al., 1991). Also, the protein content in senescing sunflower leaves was found to drop earlier in nitrogen-deficient plants than in high-nitrogen plants (Agüera et al., 2010). Changes in photosynthetic pigment contents also indicate progress of leaf senescence (Yoo et al., 2003; Guo \& Gan, 2005; Ougham et al., 2008). The chlorophyll breakdown pathways operating during leaf senescence are well-known and require pigment degradation and avoiding photodamage in order to maintain the ability to export released nutrients to other plant parts (Hörtensteiner, 
2006; Ougham et al., 2008). Chlorophylls in sunflower plants are more susceptible to degradation than are carotenoids during leaf senescence, and both total chlorophyll and carotenoid contents are high in young and mature leaves, their levels peaking at 22 days and decreasing afterwards during senescence (Fig. 1). Carotenoid degradation is usually slower than chlorophyll breakdown and can be especially complex depending on the particular pigment species (Suzuki \& Shioi, 2004).
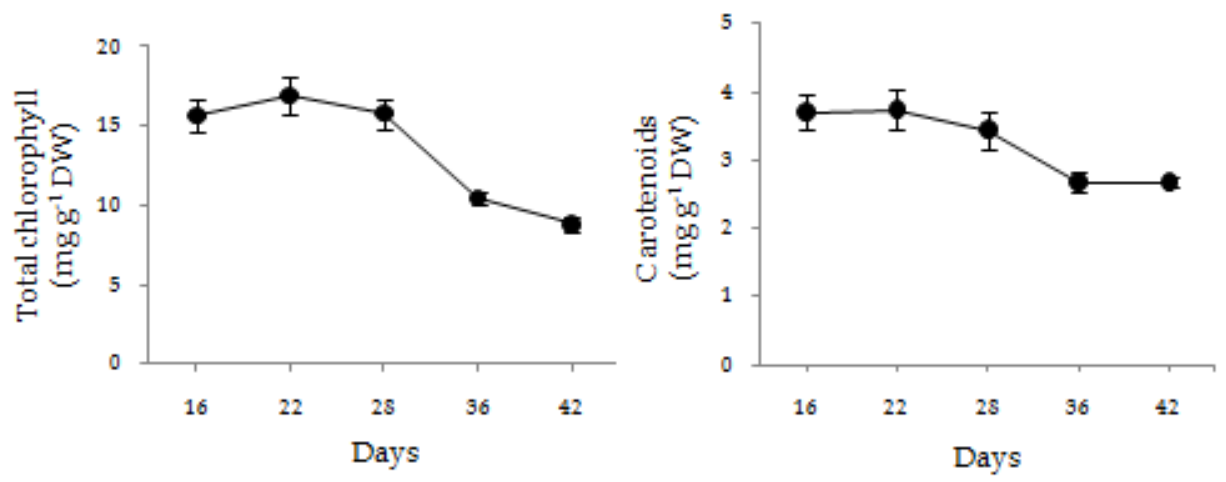

Fig. 1. Changes in pigment levels during ageing of sunflower primary leaves. Data are means \pm SD for duplicate determinations in three separated experiments.

Chlorophyll loss in sunflower plants is also a typical phenomenon of leaf senescence of potential use as an indicator. The marked decrease in total chlorophyll observed after 28 days is mainly due to the loss of chlorophyll $a$, which is the form most strongly affected by leaf ageing as revealed by a significant decrease in $\mathrm{Chl} a / \mathrm{Chl} b$ ratio in senescent leaves (Cabello et al., 2006). In radish cotyledons, however, the ratio of Chl $a$ to $\mathrm{Chl} b$ increases slightly during senescence, which suggests that $\mathrm{Chl} b$ is degraded faster than is Chl $a$ (Suzuki \& Shioi, 2004).

Other typical changes observed during senescence are a rapid decline in photosynthetic activity, which may be a senescence-inducing signal (Bleecker \& Patterson, 1997; Quirino et al., 2000), and a reduction in transpiration rate, which is probably due to an increase in abscisic acid levels inducing stomatal closure, although this is not a direct induction factor for senescence (Weaver \& Amasino, 2001). A marked decrease in $\mathrm{CO}_{2}$ fixation rate and transpiration in sunflower plants was observed during natural leaf senescence, a process that starts and develops in plants aged 28-42 days (Fig. 2).

Although natural senescence is the final stage of leaf development, it may start prematurely by effect of exposure to environmental stress or nutrient deprivation (Quirino et al., 2000; Lim et al., 2003, 2007, Wingler et al., 2009). In fact, poor nitrogen nutrition and exposure to high irradiance are known to lead to early senescence in sunflower leaves (Agüera et al., 2010). Thus, the decrease in chlorophyll content associated to leaf senescence starts earlier in sunflower plants grown with low nitrogen, which suggests that leaf senescence is accelerated under these conditions. In addition, the decline in photosynthetic activity is more apparent with nitrogen deficiency (Agüera et al., 2010). Similarly, the loss of photosynthetic activity is more marked in leaves of sunflower plants grown at high 
irradiance than in others grown at a low photon flux density, also indicating that an increased irradiance may accelerate leaf senescence.

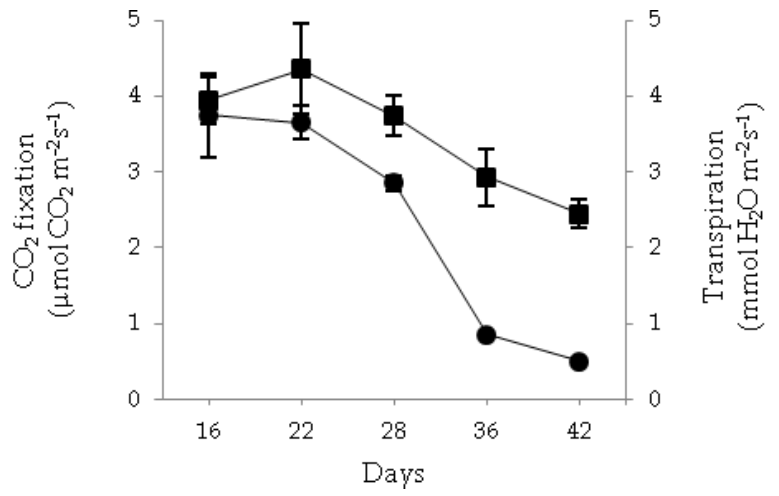

Fig. 2. Carbon dioxide fixation rates and transpiration in sunflower primary leaves of different age. Data are means \pm SD of measured values on primary leaves of ten plants randomly selected for each age.

\section{Carbon and nitrogen metabolites as regulators of leaf senescence in sunflower plants}

The contents in soluble sugars of sunflower plants increase with leaf ageing, and the opposite holds for the starch content. Our results show that accumulation of soluble sugars in plants grown at high irradiance is not much greater than in plants grown at low irradiance, although a substantial increase in the monosaccharide-to-sucrose ratio is observed at the start of senescence (especially at high irradiance levels) (Fig. 3). The accumulation of soluble sugars is associated to leaf age but unrelated to photosynthetic activity because $\mathrm{CO}_{2}$ fixation rates decrease during ageing; rather, it is due to starch hydrolysis. The increase in soluble sugars may also be ascribed to senescence causing a loss of functional and structural integrity in cell membranes, thereby boosting membrane lipid catabolism and hence sugar production by gluconeogenesis (Buchanan-Wollaston et al., 2003b; Lim et al., 2007). Leaf senescence is a plastic process triggered by a variety of external and internal factors (Weaver \& Amasino, 2001; Buchanan-Wollaston et al., 2003a; Balibrea-Lara et al., 2004; Wingler et al., 2006). Senescence reduces photosynthetic carbon fixation, but is important for the recycling of nitrogen and other nutrients (Díaz et al., 2005; Wingler et al., 2005). By virtue of its lying at the crossroads of carbon and nitrogen metabolism, senescence is regulated by carbon and nitrogen signals. Increasing evidence suggests a role for hexose accumulation in ageing leaves as a signal for either senescence initiation or acceleration in annual plants (Masclaux et al., 2000; Moore et al., 2003; Díaz et al., 2005; Masclaux-Daubresse et al., 2005; Parrott et al., 2005; Pourtau et al., 2006; Wingler \& Roitsch, 2008; Agüera et al., 2010). Recently, the role of sugar accumulation or starvation in leaf senescence was critically evaluated by van Doorn (2008), who pointed out that little is known about sugar concentrations and senescence regulation in different tissues and cells. 

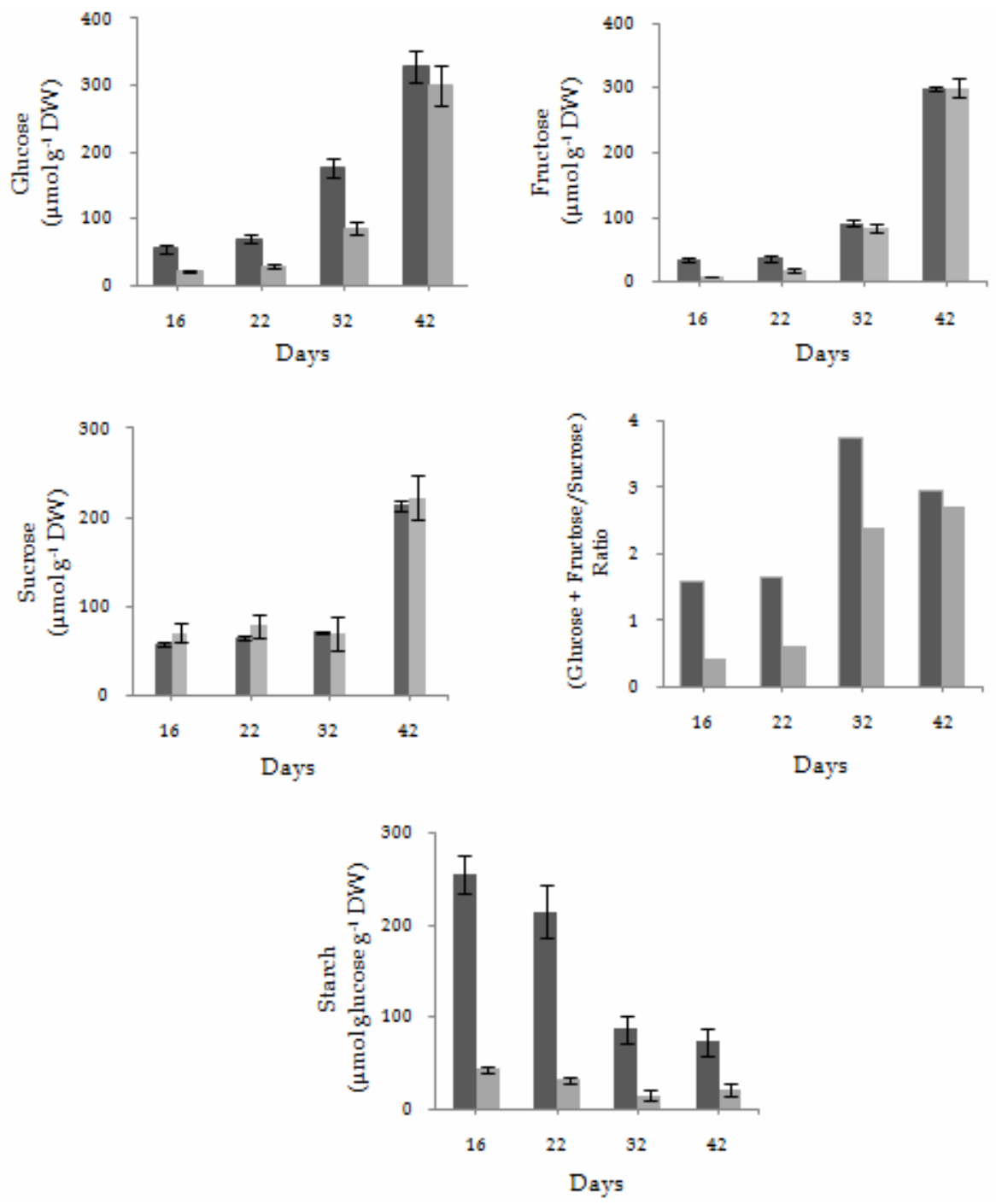

Fig. 3. Changes in glucose, fructose, sucrose and starch contents, and in hexoses-to-sucrose ratio, during development of sunflower primary leaves. Plants were grown at $125 \mu \mathrm{mol}$ photons $\mathrm{m}^{-2} \mathrm{~s}^{-1}$ (grey bars) or $350 \mu \mathrm{mol}$ photons $\mathrm{m}^{-2} \mathrm{~s}^{-1}$ (black bars). Data are means $\pm \mathrm{SD}$ for duplicate determinations in three separate experiments.

Although sugars may not always be the direct cause of leaf senescence, there is enough evidence suggesting that sugar signalling plays a role in senescence regulation in a complex network involving a variety of other signals (Masclaux-Daubresse et al., 2007; Wingler \& Roitsch, 2008; Wingler et al., 2009). Thus, cytokinin oxidase/dehydrogenase activity and senescence are positively correlated. The enzyme probably boosts senescence by destroying 
cytokinins and light is known to increase cytokinin oxidase/dehydrogenase activity during senescence of barley leaf segments (Schlüter et al., 2011).

Some results also suggest that leaf senescence is regulated by the carbon-nitrogen balance (Masclaux et al., 2000). However, in spite of the drastic changes in leaf metabolism occurring during senescence, carbon and nitrogen metabolite contents have scarcely been determined (Diaz et al., 2005). Cabello et al. (2006) found sunflower leaf senescence to be associated with significant changes in the contents of carbon and nitrogen metabolites. The highest ammonium concentrations were found in young and senescent leaves, as reported in tobacco (Masclaux et al., 2000). Our results indicate that sunflower plants exhibit their peak ammonium contents in young and late senescing leaves (Table 2). The high ammonium contents of young leaves are probably a result of strong photosynthetic nitrate reduction activity and photorespiration. In addition, young leaves have low contents in soluble carbohydrates, and sugar availability is known to be a limiting factor for ammonium assimilation (Morcuende et al., 1998). The high ammonium contents of senescent leaves are mainly due to protein degradation, amino acid deamination and nucleic acid catabolism, but also to photorespiration.

Senescent leaves contain low levels of free amino acids, probably because their remobilization is essential with a view to supplying developing organs in the plant (Buchanan-Wollaston, 1997). The concentrations of glutamate (a precursor of other amino acids) and aspartate (a direct product of glutamate transamination) decrease in the final stages of senescence in Arabidopsis. Glutamine and asparagine, the major amino acids translocated in the phloem sap, are mobilized more efficiently during late senescence (Diaz et al., 2005). As suggested by a genome array study (Lin \& Wu, 2004), the synthesis of asparagine for nitrogen remobilization during dark-induced leaf senescence in Arabidopsis seems to occur via a novel biochemical pathway. Cabello et al. (2006) found glutamate to be the most abundant free amino acid in sunflower leaves as previously also found in rice (Kamachi et al., 1991), tobacco (Masclaux et al., 2000; Tercé-Laforgue et al., 2004) and Arabidopsis (Diaz et al., 2005). The ratio (Glu + Asp)/(Gln + Asn) peaked in sunflower leaves of 22 days, but decreased gradually in leaves of 28, 36 and 42 days (Table 2), which suggests that N-rich amino acids (specially Asn, which has a lower C to $\mathrm{N}$ ratio) are produced for efficient export from leaves in late senescence, as proposed for Arabidopsis (Diaz et al., 2005).

\begin{tabular}{ccc}
\hline $\begin{array}{c}\text { Leaf age } \\
\text { (days) }\end{array}$ & $\begin{array}{c}\text { Ammonium } \\
(\mu \mathrm{mol} \mathrm{g-1} \mathrm{DW})\end{array}$ & $\begin{array}{c}\text { (Glu }+\begin{array}{c}\text { Asp } / \text { Gln }+ \text { Asn }) \\
\text { Ratio }\end{array} \\
\\
\end{array}$ \\
16 & $11.40 \pm 1.0$ & 2.11 \\
22 & $8.57 \pm 0.9$ & 2.29 \\
28 & $7.29 \pm 0.7$ & 1.77 \\
36 & $8.94 \pm 0.5$ & 1.51 \\
42 & $10.91 \pm 0.7$ & 1.44 \\
\hline
\end{tabular}

Table 2. Changes in ammonium content and glutamate + aspartate /glutamine + asparagine ratio during sunflower primary leaf ageing. Data are means \pm SD for duplicate determinations in three separated experiments 
We examined changes in glutamine synthetase (GS) expression and activity during leaf development (Cabello et al., 2006). GS, which is the key enzyme in ammonia assimilation, is present as chloroplastic (GS2) and cytosolic (GS1) isoforms in sunflower leaves (Cabello et al., 1991). In order to confirm whether these isoforms are differently affected by senescence in sunflower leaves, we determined their specific activity during plant development. As shown in Figure 4, total GS activity decreased with the leaf age. The decrease was consequence of a strong decline in chloroplastic GS2 activity. On the other hand, cytosolic GS1 activity increased with ageing. It should be noted that GS1 was the predominant isoform in senescent leaves of 42 days, but accounted for only $7 \%$ of total GS activity in young leaves (16 days). As a result, the GS2/GS1 ratio decreased from 13.3 in young leaves (16 days) to 0.9 in senescent leaves (42 days) (Fig. 4). These results indicate that leaf senescence has an adverse effect on the activity of chloroplastic GS2 (the main glutamine synthetase isoform) and reduces total GS activity despite its boosting GS1 activity.
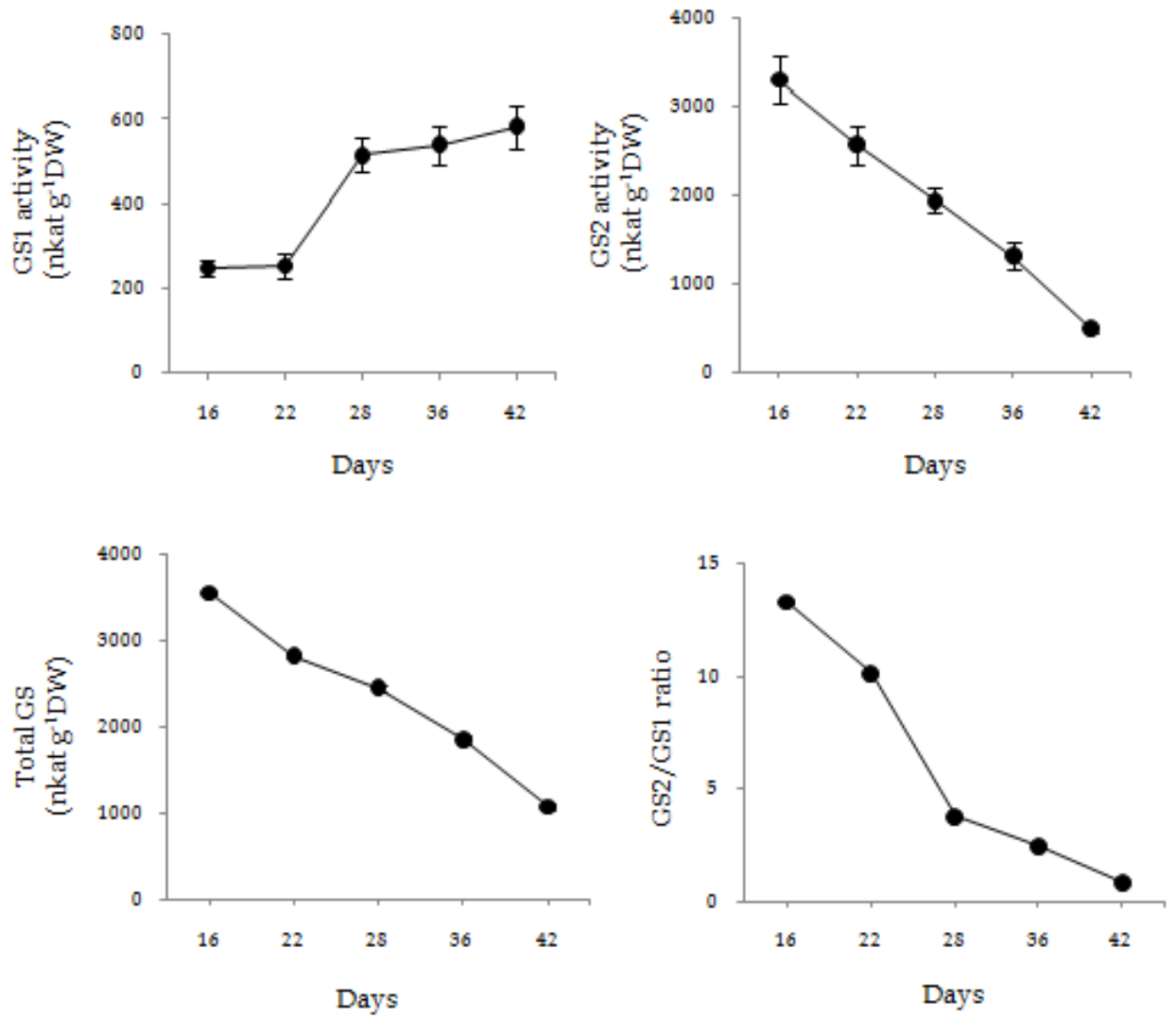

Fig. 4. Effect of ageing on total GS activity and on the activities of GS1 and GS2 isoforms in sunflower leaves. Data are means \pm SD of duplicate determinations from three separated experiments. 
Ageing affects glutamine synthetase activity but plays a direct role in the regulation of GS gene expression (Cabello et al., 2006). A Northern blot test using a probe corresponding to an internal fragment from Helianthus annuus GS2 cDNA revealed that the levels of GS2 transcripts decreased during leaf development and were very low in the late stage of senescence (42 days) (Fig. 5). Glutamine synthetase activity has been found to decrease during natural leaf senescence in a wide variety of plants including cereals, tomato and tobacco (Streit \& Feller, 1983; Kamachi et al., 1991; Pérez-Rodríguez \& Valpuesta, 1996; Masclaux et al., 2000). This loss of activity is mainly due to a gradual decrease in the major plastidial GS2 isoform since the cytosolic GS1 isoform remains constant or increases during leaf ageing (Pérez-Rodríguez \& Valpuesta, 1996; Masclaux et al., 2000).

Northern blots and immunological analyses indicate that both GS transcripts and polypeptides are affected (Pérez-Rodríguez \& Valpuesta 1996). GS1 plays a major role in the synthesis of glutamine for transport and remobilization of leaf organic nitrogen (TercéLaforgue et al., 2004), whereas GS2 takes part in the reassimilation of ammonium from photorespiration in photosynthetic tissues (Kamachi et al., 1992). The stimulation of the cytosolic GS1 isoform during senescence can be ascribed to the need for toxic ammonium to be reassimilated in order to produce glutamine for export to sink organs; this has led some authors to assume a shift in ammonia assimilation from the chloroplast to the cytosol of leaf cells during senescence (Brugière et al., 2000). Total GS activity was found to drop by a effect of a strong decrease in GS2 activity was found during sunflower leaf ageing despite the simultaneous increase in GS1 activity. GS2 transcript levels also diminished during ageing. Our results (Figs. 4 and 5) are therefore consistent with others previously reported for tomato and tobacco.

\section{Time (days)}

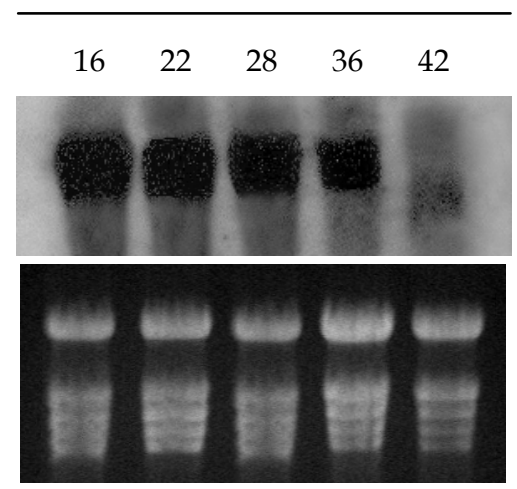

Fig. 5. Effect of ageing on GS2 mRNA accumulation in sunflower leaves.

Amino acids and other metabolites related to $\mathrm{N}$ metabolism deficit may act as signals to induce senescence in combination with hexose accumulation. Thus, leaf senescence in sunflower plants is induced by high sugar levels and accelerated by a low nitrogen supply, which supports the view that high sugar/low nitrogen conditions trigger senescence and facilitate its development (Wingler et al., 2009). Our results suggest that leaf senescence in sunflower plants is accelerated by nitrogen deficiency and high irradiance, and also that 
some factors such the levels of soluble sugars and amino acids may interact in a complex network to promote this process.

\section{Oxidative stress in sunflower plants}

Leaf senescence is an oxidative process that involves degradation of cellular and subcellular structures and macromolecules, and mobilization of the degradation products to other parts of the plants (Vanacker et al., 2006). Oxidative stress during senescence may be caused or increased by a loss of antioxidant enzymatic activities (Zimmermann \& Zentgraf, 2005; Zimmermann et al., 2006; Procházkova \& Wilhelmova, 2007). Senescence is also accompanied by an increase in ROS, one of the origins of which is an imbalance between the production and consumption of electrons in the photosynthetic electron transport chain caused by preferential inhibition of stromal reactions in contrast with photosystem II photochemistry (Špundová et al., 2003). The inhibition of stromal reactions increases the electron flow to molecular oxygen and causes ROS to accumulate and chloroplast components to be damaged as a result (Špundová et al., 2005; Couée et al., 2006). Chloroplasts are the main source of ROS in plants (Zimmermann \& Zentgraf, 2005) and also the major target of oxidative damage (Munné-Bosch \& Alegre, 2002). Stromal protein degradation during leaf senescence may be initiated by oxidative processes associated with the generation of free radicals and reactive species (Procházkova et al., 2001). Like Rubisco and other chloroplastic proteins, GS2 is susceptible to degradation initiated by reactive oxygen species (Ishida et al., 2002). The chloroplastic GS2 isoform is one of the first targets of oxidative damage at high irradiation levels (Palatnik et al., 1999). Oxidized GS becomes more susceptible to proteolysis (Ortega et al., 1999); under photo-oxidative stress, GS2 cleavage occurs preferentially around the catalytic site (Ishida et al., 2002). Senescence may therefore have a direct impact on GS2 activity through enzyme degradation initiated by reactive oxygen species as reported in Rubisco (Ishida et al., 1997; Roulin \& Feller, 1998). Our results indicate that the decrease in GS2/GS1 ratio during sunflower leaf ageing may be partly due to a different sensitivity to oxidative stress of the two isoforms; in fact, chloroplastic GS2 is much more sensitive to oxidative modification in vitro than is cytosolic GS1 (Cabello et al., 2006). Therefore, ageing induces oxidative stress in sunflower leaves and can thus have an adverse effect on chloroplastic GS2, as well as on photosynthetic pigments. Antioxidant enzyme activities in sunflower leaves were found to decline during late senescence (42 days). Similar results have been reported for tobacco (Dhindsa et al., 1981), Arabidopsis (Ye et al., 2000), pea (Olsson, 1995) and maize (Procházkova et al., 2001). Oxidative stress during late senescence may be caused or increased by the loss of antioxidant enzymatic activities (Zimmermann \& Zentgraf, 2005). Also, the decline in antioxidant activities is believed to be a consequence rather than the origin of senescence (Dertinger et al., 2003).

Susceptibility to oxidative stress depends on the overall balance between production of oxidants and cell antioxidant capability. In sunflower plants, considerable oxidative stress has been observed in vivo during leaf senescence, as revealed by lipid peroxidation, $\mathrm{H}_{2} \mathrm{O}_{2}$ accumulation and a decrease in the levels of antioxidant enzymes such as catalase, ascorbate peroxidase and superoxide dismutase (Table 3). Lipid peroxidation only occurs during the late stage of senescence (Berger et al., 2001; Jongebloed et al., 2004; Wingler et al., 2005). High irradiance causes reversible photoinhibition of photosynthesis in pea chloroplasts and 
increases ROS potentially regulating the accumulation of mRNA encoding antioxidant enzymes (Hernández et al., 2006).

\begin{tabular}{cccccc}
\hline Age & $\mathrm{H}_{2} \mathrm{O}_{2}$ & Catalase & $\begin{array}{c}\text { Ascorbate } \\
\text { peroxidase } \\
\left(\mathrm{U} \mathrm{g}^{-1} \mathrm{DW}\right)\end{array}$ & $\begin{array}{c}\text { Superoxide } \\
\text { dismutase }\end{array}$ & Lipid peroxidation \\
$($ days $)$ & $\left(\mu \mathrm{mol} \mathrm{g}{ }^{-1} \mathrm{DW}\right)$ & & & & \\
$(\mathrm{nmol} \mathrm{MDA} \mathrm{g}-1 \mathrm{DW})$ & \\
16 & $1.22 \pm 0.15$ & $1.12 \pm 0.10$ & $17.21 \pm 1.22$ & $336.4 \pm 28$ & $87.6 \pm 8.2$ \\
22 & $1.38 \pm 0.14$ & $1.70 \pm 0.12$ & $17.99 \pm 2.12$ & $356.2 \pm 39$ & $85.6 \pm 7.4$ \\
28 & $3.84 \pm 0.42$ & $2.25 \pm 0.26$ & $28.22 \pm 3.22$ & $538.5 \pm 42$ & $155.5 \pm 12.3$ \\
36 & $4.76 \pm 0.30$ & $1.94 \pm 0.17$ & $21.34 \pm 2.19$ & $1450.5 \pm 112$ & $171.5 \pm 14.5$ \\
42 & $5.28 \pm 0.51$ & $1.24 \pm 0.15$ & $14.53 \pm 1.17$ & $985.2 \pm 92$ & $188.4 \pm 12.8$ \\
\hline
\end{tabular}

Table 3. Hydrogen peroxide accumulation, catalase, ascorbate peroxidase and superoxide dismutase activities, and lipid peroxidation levels during sunflower primary leaf development. Data are means \pm SD for duplicate determinations in three separated experiments.

The activity and expression of antioxidant enzymes are seemingly sensitive to high irradiance stress (Yoshimura et al., 2000; Hernández et al., 2004).

We found $\mathrm{H}_{2} \mathrm{O}_{2}$ accumulation in senescent sunflower to be slightly more marked in plants grown under a nitrogen deficiency; the differences, however, were not large enough to assume that $\mathrm{H}_{2} \mathrm{O}_{2}$ is a major factor regulating the induction of leaf senescence in $\mathrm{N}$-deficient plants (Table 3). Interestingly, catalase and ascorbate peroxidase activity decreased steadily in plants grown with low nitrogen, but increased during early leaf development and then declined during senescence in plants grown with high nitrogen (Agüera et al., 2010). Production of ROS during leaf senescence is essentially governed by chloroplasts, which have a strong photooxidative potential (Zapata et al., 2005). A simultaneous increase in lipid peroxidation was observed. Mutations in the Arabidopsis CPR5/OLD1 gene may cause early senescence through deregulation of the cellular redox balance (Jing et al., 2008). Also, there is evidence suggesting that inadequate oxidant and carbonyl group production are intrinsically related to plant ageing, and that low mitochondrial, superoxide dismutase and ascorbate peroxidase activities may contribute to extensive protein carbonylation (Vanacker et al., 2006; Srivalli \& Khanna-Chopra, 2009).

In conclusion, during sunflower leaf development some coordinated metabolic and physiological changes are produced, and the senescence process induces significant alterations in the levels of carbon and nitrogen metabolites. Glutamine synthetase of sunflower leaves is regulated both at transcriptional and enzyme levels during leaf ontogeny. Post-translational regulation of the GS2 isoform could be due, at least partially, to oxidative processes. GS activity may be used as a biochemical marker of leaf ageing, since the beginning of senescence at about 28 days is accompanied by a drastic drop in the GS2/GS1 ratio due to the increase of the cytosolic GS1 activity and the decline of the chloroplastic GS2 activity. Our results suggest that both high irradiance and nitrogen deficiency accelerates senescence of the primary leaf, probably for maintaining the functionality of the young leaves, and that one of the reasons for this accelerated senescence 
may be the high cellular oxidation and oxidative damage caused by the earlier decline of the activity of the antioxidant enzymes in these plants (Pompelli et al., 2010).

\section{Acknowledgment}

This work was supported by Junta de Andalucía (grant P07-CVI-02627 and PAI group BIO0159) and DGICYT (AGL2009-11290).

\section{References}

Agüera, E., Cabello, P., \& de la Haba, P. (2010). Induction of leaf senescence by low nitrogen nutrition in sunflower (Helianthus annuus L.) plants. Physiologia Plantarum, Vol.138, pp. 256-267, ISSN 0031-9317

Balibrea-Lara, M.E., González-García, M.C., Fatima, T., Ehneß, R., Lee, T.K., Proels, R., Tanner, W., \& Roitsch, T. (2004). Extracellular invertase is an essential component of cytokinin-mediated delay of senescence. Plant Cell, Vol.16, pp. 1276-1287, ISSN 1040-4651

Berger, S., Weichert, H., Porzel, A., Wasternack, C., Kühn, H., \& Feussner, I. (2001). Enzymatic and non-enzymatic lipid peroxidation in leaf development. Biochimica et Biophysica Acta, Vol.1533, pp. 266-276, ISSN 0304-4165

Bleecker, A.P., \& Patterson, S.E. (1997). Last exit: Senescence, abscission, and meristem arrest in Arabidopsis. Plant Cell, Vol.9, pp. 1169-1179, ISSN 1040-4651

Buchanan-Wollaston, V. (1997). The molecular biology of leaf senescence. Journal of Experimental Botany, Vol.48, pp. 181-199, ISSN 0022-0957

Buchanan-Wollaston, V., Earl, S., Harrison, E., Mathas, E., Navabpour, S., Page, T., \& Pink, D. (2003a). The molecular analysis of leaf senescence- a genomics approach. Plant Biotechnology Journal, Vol.1, pp. 3-22, ISSN 1467-7644

Buchanan-Wollaston, V., Wellesbourne, H.R.I., \& Warwick, U.K. (2003b). Senescence, leaves, In: Encyclopedia of Applied Plant Sciences, Elsevier Academic Press, 808-816

Brugière, N., Dubois, F., Masclaux, C., Sangwan, R.S., \& Hirel, B. (2000) Immunolocalization of glutamine synthetase in senescing tobacco (Nicotiana tabacum L.) leaves suggests that ammonia assimilation is progressively shifted to the mesophyll cytosol. Planta, Vol. 211, pp. 519-527, ISSN 0032-0935

Cabello, P., de la Haba, P., \& Maldonado, J.M. (1991). Isoforms of glutamine synthetase in cotyledons, leaves and roots of sunflower plants. Journal of Plant Physiology, Vol.137, pp. 378-380, ISSN 0176-1617

Cabello, P., Agüera, E., \& de la Haba, P. (2006). Metabolic changes during natural ageing in sunflower (Helianthus annuus) leaves: expression and activity of glutamine synthetase isoforms are regulated differently during senescence. Physiologia Plantarum, Vol.128, pp. 175-185, ISSN 0031-9317

Couée, I., Sulmon, C., Gouesbet, G., \& El-Amrani, A. (2006). Involvement of soluble sugars in reactive oxygen species balance and responses to oxidative stress in plants. Journal of Experimental Botany, Vol.3, pp. 449-459, ISSN 0022-0957

Dertinger, U., Schaz, U., \& Schulze, E.D. (2003). Age-dependence of the antioxidative system in tobacco with enhanced glutathione reductase activity or senescence-induced production of cytokinins. Physiologia Plantarum, Vol.119, pp. 19-29, ISSN 0031-9317 
Dhindsa, R.A., Plumb-Dhindsa, P., \& Thorpe, T.A. (1981). Leaf senescence: correlated with increased permeability and lipid peroxidation, and decreased levels of superoxide dismutase and catalase. Journal of Experimental Botany, Vol.126, pp. 93-101, ISSN 0022-0957

Diaz, C., Purdy, S., Christ, A., Morot-Gaudry, J.F., Wingler, A., \& Masclaux-Daubresse, C. (2005). Characterization of markers to determine the extent and variability of leaf senescence in Arabidopsis. A metabolic profiling approach. Plant Physiology, Vol.138, pp. 898-908, ISSN 0032-0889

Diaz, C., Lemaître, T., Christ, A., Azzopardi, M., Kato, Y., Sato, F., Morot-Gaudry, J.F., Le Dily, F., \& Masclaux-Daubresse, C. (2008). Nitrogen recycling and remobilization are differentially controlled by leaf senescence and development stage in Arabidopsis under low nitrogen nutrition. Plant Physiology, Vol.147, pp. 1437-1449, ISSN 0032-0889

Gan, S., \& Amasino, R.M. (1997). Making sense of senescence. Plant Physiology, Vol.113, pp. 313-319, ISSN 0032-0889

Gepstein, S. (1988). Photosynthesis, In: Senescence and Aging in Plants, L.D. Noodén \& A.C. Leopold, (Eds.), 85-109, Academic Press Publishers, San Diego, USA

Guiboileau, A., Sormani, R., Meyer, C., \& Masclaux-Daubresse, C. (2010). Senescence and death of plant organs: nutrient recycling and developmental regulation. Comptes Rendus Biologies, Vol.333, pp. 382-391 ISSN 1631-0691

Guo, I., \& Gan, S. (2005). Leaf senescence: signals, execution, and regulation. Current Topics in Developmental Biology, Vol.71, pp. 83-112, ISSN 0070-2153

Hernández, J.A., Escobar, C., Creissen, G., \& Mullineaux, P.M. (2004). Role of hydrogen peroxide and the redox state of ascorbate in the induction of antioxidant enzymes in pea leaves under excess light stress. Functional Plant Biology, Vol.31, pp. 359-368, ISSN 1445-4408

Hernández, J.A., Escobar, C., Creissen, G., \& Mullineaux, P.M. (2006). Antioxidant enzyme in pea plants under high irradiance. Biologia Plantarum, Vol.50, pp. 395-399, ISSN 0006-3134

Hidema, J., Makino, A., Mae, T., \& Ojima, T. (1991). Photosynthetic characteristics of rice leaves aged under different irradiances from full expansion through senescence. Plant Physiology, Vol.97, pp.1287-1293, ISSN 0032-0889

Himelblau, E., \& Amasino, R.M. (2001). Nutrients mobilized from leaves of Arabidopsis thaliana during senescence. Journal of Plant Physiology, Vol.158, pp. 1317-1323, ISSN 0176-1617

Hörtensteiner, S. (2006). Chlorophyll degradation during senescence. Annual Review of Plant Biology, Vol.57, pp. 55-77, ISSN 1543-5008

Hörtensteiner, S., \& Feller, U. (2002). Nitrogen metabolism and remobilization during senescence. Journal of Experimental Botany, Vol.53, pp. 927-937, ISSN 0022-0957

Ishida, H., Nishimori, Y., Sugisawa, M., Makino, A., \& Mae, T. (1997). The large subunit of ribulose-1,5-bisphosphate carboxilase/oxygenase is fragmented into $37 \mathrm{kDa}$ and 16 $\mathrm{kDa}$ polypeptides by active oxygen in the lysates of chloroplasts from primary leaves of wheat. Plant and Cell Physiology, Vol. 38, pp. 471-479, ISSN 0032-0781 
Ishida, H., Anzawa, D., Kokubun, N., Makino, A., \& Mae, T. (2002). Direct evidence for nonenzymatic fragmentation of chloroplastic glutamine synthetase by a reactive oxygen species. Plant Cell and Environment, Vol.25, pp. 625-631, ISSN 0140-7791

Jing, H.C., Hebeler, R., Oeljeklaus, S., Sitek, B., Stühler, K., Meyer, H.E., Sturre, M.J., Hille, J., Warscheid, B., \& Dijkwell, P.P. (2008). Early leaf senescence is associated with an altered cellular redox balance in Arabidopsis cpr5/old1 mutants. Plant Biology, Vol.1, pp. 85-98, ISSN 1435-8603

Jongebloed, U., Szederkényi, J., Hartig, K., Schobert, C., \& Komor, E. (2004). Sequence of morphological and physiological events during natural ageing and senescence of a castor bean leaf: sieve tube occlusion and carbohydrate back-up precede chlorophyll degradation. Physiologia Plantarum, Vol.120, pp. 338-346, ISSN 00319317

Kamachi, K., Yamaya, T., Mae, T., \& Ojiva, K. (1991). A role for glutamine synthetase in the remobilization of leaf nitrogen during natural senescence in rice leaves. Plant Physiology, Vol.96, pp. 411-417, ISSN 0032-0889

Kamachi, K., Yamaya, T., Hayakawa, T., Mae, T., \& Ojima, K. (1992). Changes in cytosolic glutamine synthetase polypeptide and its mRNA in a leaf blade of rice plants during natural senescence. Plant Physiology, Vol.98, pp. 1323-1329, ISSN 0032-0889

Kato, Y., Murakami, S., Yamamoto, Y., Chatani, H., Kondo, Y., Nakano, T., Yokota, A., \& Sato, F. (2004). The DNA-binding protease, CND41, and the degradation of ribulose-1,5-bisphosphate carboxylase/oxygenase in senescent leaves of tobacco. Planta, Vol.220, pp. 97-104, ISSN 0032-0935

Kato, Y., Yamamoto, Y., Murakami, S., Sato, F. (2005). Post-translational regulation of CND41 protease activity in senescent tobacco leaves. Planta, Vol.222, pp. 643-651, ISSN 0032-0935

Kukavica, B., \& Veljovic-Jovanovic, S. (2004). Senescence-related changes in the antioxidant status of ginkgo and birch leaves during autumn yellowing. Physiologia Plantarum, Vol.122, pp. 321-327, ISSN 0031-9317

Lim, P.O., Woo, H.R., \& Nam, H.G. (2003). Molecular genetics of leaf senescence in Arabidopsis. Trends in Plant Science, Vol.8, pp. 272-278, ISSN 1360-1385

Lim, P.O., Kim, H.J., \& Nam, H.G. (2007). Leaf senescence. Annual Review of Plant Biology, Vol.58, pp. 115-136, ISSN 1543-5008

Lin, J.F., \& Wu, S.H. (2004). Molecular events in senescing Arabidopsis leaves. Plant Journal, Vol.39, pp. 612-628, ISSN 0960-7412

Martínez, D.E., Costa, M.L., \& Guiamet, J.J. (2008). Senescence-associated degradation of chloroplast proteins inside and outside the organelle. Plant Biology, Vol.1, pp.15-22, ISSN 1435-8603

Masclaux, C., Valadier, M.H., Brugière, N., Morot-Gaudry, J.F., \& Hirel, B. (2000). Characterization of the sink/source transition in tobacco (Nicotiana tabacum L.) shoots in relation to nitrogen management and leaf senescence. Planta, Vol.211, pp. 510-518, ISSN 0032-0935

Masclaux-Daubresse, C., Carrayol, E., \& Valadier, M.H. (2005). The two nitrogen mobilization- and senescence-associated GS1 and GDH genes are controlled by C and N metabolites. Planta, Vol.221, pp. 580-588, ISSN 0032-0935 
Masclaux-Daubresse, C., Purdy, S., Lemaître, T., Pourtau, N., Naconnat, L., Renou, J.P., \& Wingler, A. (2007). Genetic variations suggest interaction between cold acclimation and metabolic regulation of leaf senescence. Plant Physiology, Vol.143, pp. 434-446, ISSN 0032-0889

Miller, A., Schlagnhaufer, C., Spalding, M., \& Rodermel, S. (2000). Carbohydrate regulation of leaf development: prolongation of leaf senescence in Rubisco antisense mutants of tobacco. Photosynthesis Research, Vol.63, pp. 1-8, ISSN 0166-8595

Moore, B., Zhou, L., Rollanf, F., Hall, Q., Cheng, W.H., Liu, Y.X., Hwang, I., Jones, T., \& Sheen, J. (2003). Role of the Arabidopsis glucose sensor HXK1 in nutrient, light and hormonal signalling. Science, Vol.300, pp. 332-336, ISSN 0036-8075

Morcuende, R., Krapp, A., Hurry, V., \& Stitt, M. (1998). Sucrose-feeding leads to increased rates of nitrate assimilation, increased rates of $\alpha$-oxoglutarate synthesis, and increased synthesis of a wide spectrum of amino acids in tobacco leaves. Planta, Vol.206, pp. 394-409, ISSN 0032-0935

Munné-Bosch, S., \& Alegre, L. (2002). Plant aging increases oxidative stress in chloroplasts. Planta, Vol.214, pp. 608-615, ISSN 0032-0935

Nam, H.G. (1997). The molecular genetic analysis of leaf senescence. Current Opinion in Biotechnology, Vol.8, pp. 200-207, ISSN 0958-1669

Noodén, L.D., Guiamét, J.J., \& John, I. (1997). Senescence mechanisms. Physiologia Plantarum, Vol.101, pp. 746-753, ISSN 0031-9317

Olsson, M. (1995). Alteration in lipid composition and antioxidative protection during senescence in drought stressed plants and non-drought stressed plants of Pisum sativum. Plant Physiology and Biochemistry, Vol.33, pp. 547-553, ISSN 0981-9428

Ortega, J.L., Roche, D., \& Sengupta-Gopalan, C. (1999). Oxidative turnover of soybean root glutamine synthetase. In vitro and in vivo studies. Plant Physiology, Vol.119, pp. 1483-1495, ISSN 0032-0889

Otegui, M., Noh, Y.S., Martínez, D.E., Vila-Petroff, M., Staehelin, A., Amasino, R., \& Guiamet, J.J. (2005). Senescence-associated vacuoles with intense proteolytic activity develop in senescing leaves of Arabidopsis and soybean. Plant Journal, Vol.41, pp. 831-844, ISSN 0960-7412

Ougham, H., Hörtensteiner, S., Armstead, I., Donnison, I., King, I., Thomas, H., \& Mur, L. (2008). The control of chlorophyll catabolism and the status of yellowing as a biomarker of leaf senescence. Plant Biology, Vol.10, pp. 4-14, ISSN 1435-8603

Palatnik, J.F., Carrillo, N., \& Valle, E.M. (1999). The role of photosynthetic electron transport in the oxidative degradation of chloroplastic glutamine synthetase. Plant Physiology, Vol.121, pp. 471-478, ISSN 0032-0889

Parrott, D., Yang, L., Shama, L., \& Fischer, A.M. (2005). Senecence is accelerated, and several proteases are induced by carbon "feast" conditions in barley (Hordeum vulgare L.) leaves. Planta, Vol.222, pp. 989-1000, ISSN 0032-0935

Pérez-Rodríguez, J., \& Valpuesta, V. (1996). Expression of glutamine synthetase genes during natural senescence of tomato leaves. Physiologia Plantarum, Vol.97, pp. 576582, ISSN 0031-9317

Pompelli, M.F., Martins, S., Antunes, W.C., Chaves, A., \& DaMatta, F.M. (2010). Photosynthesis and photoprotection in coffee leaves is affected by nitrogen and 
light availabilities in winter conditions. Journal of Plant Physiology, Vol.167, pp. 1052-1060, ISSN 0176-1617

Pourtau, N., Jennings, R., Pelzer, E., Pallas, J., \& Wingler, A. (2006). Effect of sugar-induced senescence on gene expression and implications for the regulation of senescence in Arabidopsis. Planta, Vol.224, pp. 556-568, ISSN 0032-0935

Prochazkova, D., Sairam, R.K., Srivastava, G.C., \& Singh, D.V. (2001). Oxidative stress and antioxidant activity as the basis of senescence in maize leaves. Plant Science, Vol.161, pp. 765-771, ISSN 0168-9452

Procházkova, D., \& Wilhelmova, N. (2007). Leaf senescence and activities of the antioxidant enzymes. Biologia Plantarum, Vol.51, pp. 401-406, ISNN 0006-3134

Quirino, B.F., Noh, Y.S., Himelblau, E., \& Amasino, R.M. (2000). Molecular aspects of leaf senescence. Trends in Plant Science, Vol.5, pp. 278-282, ISSN 1360-1385

Roulin, S., \& Feller, U. (1998). Dithiothreitol triggers photo-oxidative stress and fragmentation of the large subunit of ribulose-1,5-bisphosphate carboxylase/oxygenase in intact pea chloroplasts. Plant Physiology and Biochemistry, Vol.36, pp. 849-856, ISSN 0981-9428

Schlüter, T., Leide, J., \& Conrad, K. (2011). Light promotes an increase of cytokinin oxidase/dehydrogenase activity during senescence of barley leaf segments. Journal of Plant Physiology, Vol.168, pp. 694-698, ISSN 0176-1617

Špundová, M., Popelková, H., Ilík, P., Skotnica, J., Novotný, R., \& Nauš, J. (2003). Ultrastructural and functional changes in the chloroplasts of detached barley leaves senescing under dark and light conditions. Journal of Plant Physiology, Vol.160, pp. 1051-1058, ISSN 0176-1617

Špundová, M., Sloukova, K., Hunková, M., \& Nauš, J. (2005). Plant shading increases lipid peroxidation and intensifies senescence-induced changes in photosynthesis and activities of ascorbate peroxidase and glutathione reductase in wheat. Photosynthetica, Vol.43, pp. 403-409, ISSN 0300-3604

Srivalli, S., \& Khanna-Chopra, R. (2009). Delayed wheat flat leaf senescence due to removal of spikelets is associated with increased activities of leaf antioxidant enzymes, reduced glutathione/oxidized glutathione ratio and oxidative damage to mitochondrial proteins. Plant Physiology and Biochemistry, Vol.47, pp. 663-670, ISSN 0981-9428

Streit, L., \& Feller, U. (1983). Changing activities and different resistance to proteolytic activity of two forms of glutamine synthetase in wheat leaves during senescence. Physiologie Végétale, Vol.21, pp. 103-108, ISSN 0031-9368

Suzuki, Y., \& Shioi, Y. (2004). Changes in chlorophyll and carotenoid contents in radish (Raphanus sativus) cotyledons show different time courses during senescence. Physiologia Plantarum, Vol.122, pp. 291-296, ISSN 0031-9317

Taiz, L., \& Zeiger, E. (2010). Plant Physiology (5 $5^{\text {th }}$ edition). Sinauer Associates Inc., ISBN 9780-87893-866-7, Sunderland, Massachusetts USA

Tercé-Laforgue, T., Mäck, G., \& Hirel, B. (2004). New insights towards the function of glutamate dehydrogenase revealed during source-sink transition of tobacco (Nicotiana tabacum) plants grown under different nitrogen regimes. Physiologia Plantarum, Vol.120, pp. 220-228, ISSN 0031-9317 
Van Doorn, V.G. (2008). Is the onset of senescence in leaf cells of intact plants due to low or high sugars level? Journal of Experimental Botany, Vol.59, pp. 1963-1972, ISSN 00220957

Van Lijsebettens, M., \& Clarke, J. (1998). Leaf development in Arabidopsis. Plant Physiology and Biochemistry, Vol.36, pp. 47-60, ISSN 0981-9428

Vanacker, H., Sandalio, L.M., Jiménez, A., Palma, J.M., Corpas, F.J., Meseguer, V., Gómez, M., Sevilla, F., Leterrier, M., Foyer, C.H., \& del Río, L.A. (2006). Roles for redox regulation in leaf senescence of pea plants grown on different sources of nitrogen nutrition. Journal of Experimental Botany, Vol.57, pp. 1735-1745, ISSN 0022-0957

Weaver, L.M., \& Amasino, R.M. (2001). Senescence is induced in individually darkened Arabidopsis leaves, but inhibited in whole darkened plants. Plant Physiology, Vol.127, pp. 876-886, ISSN 0032-0889

Wiedemuth, K., Müller, J., Kahlau, A., Amme, S., Mock, H.-P., Grzam, A., Hell, R., Egle, K., Beschow, H., \& Humbeck, K. (2005). Successive maduration and senescence of individual leaves during barley whole plant ontogeny reveals temporal and spatial regulation of photosynthetic function in conjunction with $\mathrm{C}$ and $\mathrm{N}$ metabolism. Journal of Plant Physiology, Vol.162, pp. 1226-1236, ISSN 0176-1617

Wingler, A., \& Roitsch, T. (2008). Metabolic regulation of leaf senescence: interactions of sugar signalling with biotic and abiotic stress response. Plant Biology, Vol.10, pp. 5062, ISSN 1435-8603

Wingler, A., Bownhill, E., \& Pourtau, N. (2005). Mechanisms of light-dependent induction of cell death in tobacco plants with delayed senescence. Journal of Experimental Botany, Vol.56, pp. 2897-2905, ISSN 0022-0957

Wingler, A., Purdy, S., Maclean, J.A., \& Pourtau, N. (2006). The role of sugars in integrating environmental signals during the regulation of leaf senescence. Journal of Experimental Botany, Vol.57, pp. 391-399, ISSN 0022-0957

Wingler, A., Maxclaux-Daubresse, C., \& Fischer, A.M. (2009). Sugars, senescence, and ageing in plants and heterotrophic organisms. Journal of Experimental Botany, Vol.60, pp. 1063-1066, ISSN 0022-0957

Ye, Z., Rodríguez, R., Tran, A., Hoang, H., de los Santos, D., Brown, S., \& Vellanoweth, R.L. (2000). The development transition to flowering repress ascorbate peroxidase activity and induces enzymatic lipid peroxidation in leaf tissue in Arabidopsis thaliana. Plant Science, Vol.158, pp. 115-127, ISSN 0168-9452

Yoo, S.D., Greer, D.H., Laing, W.A., \& McManus, M.T. (2003). Changes in photosynthetic efficiency and carotenoid composition in leaves of white clover at different developmental stages. Plant Physiology and Biochemistry, Vol.4, pp. 887-893, ISSN 0981-9428

Yoshimura, K., Yabuta, Y., Ishikawa, T., \& Shigeoka, S. (2000). Expression of spinach ascorbate peroxidase isoenzymes in response to oxidative stress. Plant Physiology, Vol.123, pp. 223-233, ISSN 0032-0889

Zapata, J.M., Guéra, A., Esteban-Carrasco, A., Martin, M., \& Sabater, B. (2005). Chloroplasts regulate leaf senescence: delayed senescence in transgenic $n d h \mathrm{~F}$-defective tobacco. Cell Death and Differentiation, Vol.12, pp. 1277-1284, ISSN 1350-9047 
Zimmermann, P., \& Zentgraf, U. (2005). The correlation between oxidative stress and leaf senescence during plant development. Cellular \& Molecular Biology Letters, Vol.10, pp. 515-534, ISSN 1425-8153

Zimmermann, P., Heinlein, C., Orendi, G., \& Zentgraf, U. (2006). Senescence-specific regulation of catalases in Arabidopsis thaliana (L.) Heynh. Plant Cell and Environment, Vol.29, pp. 1049-1060, ISSN 0140-7791 


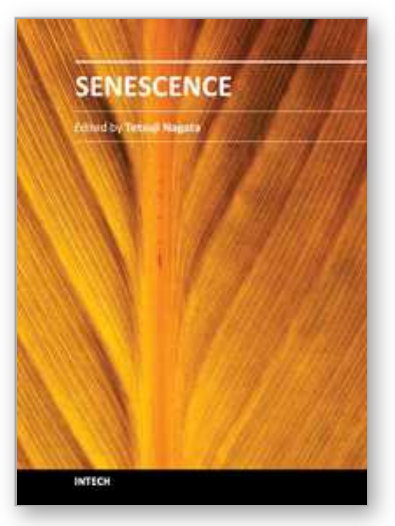

\author{
Senescence \\ Edited by Dr. Tetsuji Nagata
}

ISBN 978-953-51-0144-4

Hard cover, 850 pages

Publisher InTech

Published online 29, February, 2012

Published in print edition February, 2012

The book "Senescence" is aimed to describe all the phenomena related to aging and senescence of all forms of life on Earth, i.e. plants, animals and the human beings. The book contains 36 carefully reviewed chapters written by different authors, aiming to describe the aging and senescent changes of living creatures, i.e. plants and animals.

\title{
How to reference
}

In order to correctly reference this scholarly work, feel free to copy and paste the following:

Eloísa Agüera, Purificación Cabello, Lourdes de la Mata, Estefanía Molina and Purificación de la Haba (2012). Metabolic Regulation of Leaf Senescence in Sunflower (Helianthus annuus L.) Plants, Senescence, Dr. Tetsuji Nagata (Ed.), ISBN: 978-953-51-0144-4, InTech, Available from:

http://www.intechopen.com/books/senescence/metabolic-regulation-of-leaf-senescence-in-sunflowerhelianthus-annuus---plants

\section{INTECH}

open science | open minds

\author{
InTech Europe \\ University Campus STeP Ri \\ Slavka Krautzeka 83/A \\ 51000 Rijeka, Croatia \\ Phone: +385 (51) 770447 \\ Fax: +385 (51) 686166 \\ www.intechopen.com
}

\author{
InTech China \\ Unit 405, Office Block, Hotel Equatorial Shanghai \\ No.65, Yan An Road (West), Shanghai, 200040, China \\ 中国上海市延安西路65号上海国际贵都大饭店办公楼405单元 \\ Phone: +86-21-62489820 \\ Fax: $+86-21-62489821$
}


(C) 2012 The Author(s). Licensee IntechOpen. This is an open access article distributed under the terms of the Creative Commons Attribution 3.0 License, which permits unrestricted use, distribution, and reproduction in any medium, provided the original work is properly cited. 